\title{
A BROADER SPECTRUM OF SJOGREN'S SYNDROME AND ITS PATHOGENETIC IMPLICATIONS
}

\author{
BY \\ JOSEPH J. BUNIM \\ National Institute of Arthritis and Metabolic Diseases, National Institutes of Health, Bethesda, Maryland
}

Your invitation to deliver the 1960 Heberden Oration is a great honour which I cherish especially because of the profound respect my colleagues of the American Rheumatism Association and I have for the major contributions that the members of the Heberden Society have made toward a better understanding of the rheumatic diseases. The nature of the studies I wish to report in this lecture conforms rather obediently to the counsel given by the eminent biochemist, Professor A. Neuberger (1960), who terminated the preceding Heberden Oration "by expressing the belief that a study ... particularly of the immunological reactions observed, may be more helpful to an understanding of connective tissue diseases than elucidation of collagen metabolism, important and interesting enough though this is to the biochemist and general biologist".

\section{History}

The history of the synthesis of Sjøgren's syndrome is quite interesting. Filamentary keratitis, one of the components of the syndrome, was first described by Leber (1882). However, the association of filamentary keratitis with disease of the lacrimal gland and deficiency of tears was not recognized until much later by Stock (1925). At a meeting of the Clinical Society of London, Hadden of St. Thomas's Hospital reported a case of " "dry mouth' or suppression of the salivary and buccal secretions" (Hadden, 1888). The patient was a widow of 65 , who had xerostomia, and in addition deficiency of lacrimal secretions. "The woman told me", wrote Hadden, "that she had occasion

\footnotetext{
* Delivered on December 2, 1960, at the Wellcome Foundation,
} London. to cry but no tears would come ... Nothing unusual could be detected by sight and by palpation in the parotid and submaxillary regions. There was no local affection of the lacrimal apparatus." At the same meeting another case of "dry mouth" was reported by Sir Jonathan Hutchinson. The first report of the association of filamentary keratitis and joint disease appeared in the following year; Fischer (1889) noted a case of combined "arthritis deformans" and keratitis filiformis. The significance of this association was emphasized by a paper read before the Ophthalmological Society of the United Kingdom by Mulock Houwer of Amsterdam (Houwer, 1927). This report included ten patients with "keratitis filamentosa" of whom six had arthritis. Houwer wrote, "It was difficult, however, to get more facts regarding the nature of the arthritis as most patients did not like to submit to a clinical examination. We imagined that possibly we were dealing with cases of irregular gout. This possibility occurred to us on examining patient No. 9 (a woman of 60), where the $x$-ray examination of the hands revealed some changes suggesting gout." Houwer ended his paper with the following sentence: "As in England gout seems to be far more prevalent than in the Netherlands, I am very curious to learn whether any of you have come across similar cases." J. Gray Clegg of Manchester replied that he had indeed noted on several occasions "conjunctivitis associated with rheumatoid or arthritic conditions (which) occurred chiefly, if not invariably in women, one of whom had peliosis rheumatica, and there was no tear secretion (Clegg, 1927).

In 1933, Henrik Sjøgren published his monograph on "A New Conception of Keratoconjunctivitis Sicca". With precision and thoroughness, 
he correctly described many of the clinical components of the syndrome which now bears his name, as well as the histopathological changes in the conjunctiva, cornea, lacrimal and salivary glands, and mucous glands of the laryngeal wall. Sjøgren concluded that "the frequent coincidence of ocular changes and hypofunction of lacrimal glands with diminution of salivary secretion, arthritic changes, and other symptoms generally found, indicates that we have to deal here with a general disease". The original series (Sjøgren, 1933) consisted of nineteen cases. By 1951, it had increased to eighty, of which 62 per cent. had polyarthritis (Sjøgren, 1951). During the decade from 1947 to 1956, five papers were published by other authors (Table I) which presented the converse, namely, the occurrence of keratoconjunctivitis sicca (KCS) or some of its components in rheumatoid arthritis. Collectively 153 such cases were found among 1,213 of rheumatoid arthritis, a mean prevalence of 13 per cent.

TABLE I

OCCURRENCE OF KERATOCONJUNCTIVITIS IN RHEUMATOID ARTHRITIS

\begin{tabular}{|c|c|c|c|c|}
\hline Author & Year & $\begin{array}{l}\text { Cases of } \\
\text { Rheuma- } \\
\text { toid } \\
\text { Arthritis }\end{array}$ & $\begin{array}{l}\text { Cases of } \\
\text { Kerato- } \\
\text { conjunc- } \\
\text { tivitis }\end{array}$ & Percentage \\
\hline $\begin{array}{l}\text { Stenstam . . } \\
\text { Reader, Whyte, and Elmes } \\
\text { Lackington, Charlin, and }\end{array}$ & $\begin{array}{l}1947 \\
1951\end{array}$ & $\begin{array}{r}435 \\
62\end{array}$ & $\begin{array}{l}46 \\
20\end{array}$ & $\begin{array}{l}11 \\
32\end{array}$ \\
\hline $\begin{array}{lll}\text { Gormaz } & \cdots & \ldots \\
\text { Gaulhofer } & \cdots & \cdots \\
\text { Thompson and Eadie } & \ldots\end{array}$ & $\begin{array}{l}1951 \\
1954 \\
1956\end{array}$ & $\begin{array}{r}50 \\
456 \\
210\end{array}$ & $\begin{array}{l}17 \\
40 \\
30\end{array}$ & $\begin{array}{r}34 \\
9 \\
14\end{array}$ \\
\hline Total & . & 1,213 & 153 & 13 \\
\hline
\end{tabular}

Some confusion has arisen about the terms Mikulicz's disease, Mikulicz's syndrome, and Sjøgren's syndrome. In 1888, Mikulicz reported the first case of benign, symmetrical, painless enlargement of the lacrimal and salivary glands, but dryness of the eyes or mouth was not noted (these findings were published in 1892). The term Mikulicz's disease has been used to designate those cases in which enlargement of the glands was caused by diffuse infiltration of lymphoid tissue, as described by Mikulicz in his original paper. The broader term, Mikulicz's syndrome, has been used to include in addition enlargement of the salivary and lacrimal glands produced by leukaemia, malignant lymphoma, tuberculosis, sarcoidosis, and other diseases. The relationship between Mikulicz's disease and Sjøgren's syndrome was clarified by Morgan and Castleman (1953) and Morgan (1954), who concluded that the pathological changes in the salivary glands in both conditions were identical and $\bar{\Xi}$ that "the condition characterized by chronic $\bar{\varrho}$. enlargement of the salivary or lacrimal glands, which in the past has been called Mikulicz's disease, may be a less highly-developed variant of a largersymptom complex, Sjøgren's syndrome".

In the literature on both Mikulicz's disease and $\frac{\bar{\sigma}}{\bar{p}}$ Sjøgren's syndrome, one finds repeated mention $\widehat{\nabla}$ of the similarity between the pathological changes in the lacrimal and salivary glands in these dis- $\infty$ orders and those in the thyroid gland in Hashimoto's $\vec{O}$ thyroiditis. The first to draw attention to this $\overrightarrow{-}$ analogy, we might add, was Hashimoto himself, in ${ }_{\sigma}^{\omega}$ his original paper of 1912. The more recent@ discovery by Roitt and Doniach (1958) and Witebsky, Rose, Terplan, Paine, and Egan (1957) of circulating. antibodies to thyroglobulin and thyrotoxic thyroid.tissue in patients with Hashimoto's disease led $\vec{\circ}$ Jones (1958) to search for organ-specific antibodies in patients with Sjøgren's syndrome. Using the $\overrightarrow{\vec{z}}$ agar-gel diffusion precipitin test, Jones found antibodies to extracts of human lacrimal and salivary glands in the sera of three of 44 patients with $\vec{\bullet}$ Sjøgren's syndrome. Jones's report was the final stimulus that activated our clinical and laboratory investigations of Sjøgren's syndrome. Some observations made in the course of these investigations have been previously reported (Bloch, Wohl, Ship, Oglesby, and Bunim, 1960; Bloch, Bunim, Wohl, and Zvaifler, 1960).

\section{The National Institutes of Health Series}

This study exemplifies the type of multidisciplinary clinical research for which the facilities and organization of the N.I.H. are especially well designed. In less than 2 years, we were fortunate enough to $\frac{5}{3}$ assemble forty cases of Sjøgren's syndrome. Most of the patients were admitted to the Arthritis Branch of the National Institute of Arthritis and Metabolic Diseases and several to the Ophthal-은 mology and Neurology Branches of the National Institute of Neurological Diseases and Blindness. My principal co-workers were Drs. Kurt Bloch, N Martin Wohl, Richard Oglesby, and Irwin Ship. N Their loyal and effective assistance made this study possible. I am especially indebted to Dr. Blochw whose resourcefulness contributed major strength? to this project.

Clinical, Pathological, and Laboratory Components
of Sjøgren's Syndrome

The diagnosis of Sjøgren's syndrome is generally based on a triad of keratoconjunctivitis sicca, $\frac{\overparen{D}}{\mathbb{D}}$ xerostomia (with or without enlargement of the $\frac{\varrho}{\sigma}$ 
salivary glands), and rheumatoid arthritis (Sjøgren, 1933), but it may also be made when any two of these three features are present (Morgan, 1954). In some cases of Sjøgren's syndrome, systemic lupus erythematosus (Morgan, 1954), scleroderma (Oblatt, Fehér, and Csiky, 1958), or polyarteritis nodosa (Ramage and Kinnear, 1956) may replace rheumatoid arthritis in Sjøgren's complex. Observations made in the course of the present study make it likely that a fourth major component, the presence of rheumatoid factor, might be added to the diagnostic criteria.

The numerous case reports that have appeared since Sjøgren's monograph was first published have added a number of components to the original syndrome. In Table II the list is brought up to date. We have added six items which are noteworthy because of their occurrence in cases of Sjøgren's syndrome without rheumatoid arthritis; namely, rheumatoid factor, complement-fixing antibodies to tissue components, thyroglobulin antibodies, arteritis, focal myositis, and neuropathy. We have also added two diseases not previously associated with this syndrome, namely myopathy or polymyositis (four cases) and Hashimoto's thyroiditis (two cases).

TABLE II

COMPONENTS OF SJØGREN'S SYNDROME

I. Manifestations of Exocrine Gland Disorder

Keratoconjunctivitis sicca Pharyngo-laryngo-rhinitis Xerostomia

Serostomia
Enlarged salivary and lacrimal
Tracheo-bronchitis (atelec-

glands

Dental caries

Tracheo-bronchitis
tasis, pleuritis*)

Vaginitis

Achlorhydria

$\begin{array}{ll}\text { II. Manifestations of Other Organ Involvement } \\ \text { Rheumatoid arthritis } & \text { Neuropathy } \\ \text { Splenomegaly } & \text { Alopecia } \\ \text { Hepatomegaly } & \text { Blood } \\ \text { Raynaud's phenomenon } & \text { Eosinophilia } \\ \text { Purpura } & \text { Leucopenia } \\ \text { Arteritis } & \text { Thrombocytopenia } \\ \text { Focal myositis } & \end{array}$

\section{Protein Abnormalities}

Hyperglobulinaemia Cephalin flocculation Thymol turbidity

Rheumatoid factor

Tissue antibodies

Thyroglobulin antibodies

* Pleuritis may be secondary to, or independent of, pulmonary parenchymal lesions.

The series studied at the N.I.H. consisted of forty patients. All but one were women. The ages ranged from 16 to 75 years (mean 50). The diagnosis was based on symptoms of dryness of the eyes, nose, mouth, or throat, and on the objective evidence of keratoconjunctivitis sicca, xerostomia and rheu- matoid arthritis. At least two of these three conditions were present in all cases.

Clinical Subgroups of Sjøgren's Syndrome.-The cases in this series fall conveniently into five subgroups on the basis of combinations of components of the syndrome (Table III).

Group A, Sjøgren's syndrome associated with classical or definite rheumatoid arthritis (17 cases);

Group B, Sjøgren's syndrome associated with possible rheumatoid arthritis ( 2 cases);

Group C, Sjøgren's syndrome associated with scleroderma ( 2 cases);

Group D, Sjøgren's syndrome associated with myopathy (4 cases);

Group E, keratoconjunctivitis and xerostomia not associated with any other disease (15 cases).

TABLE III

CLINICAL SUB-GROUPS OF SJøGREN'S SYNDROME

\begin{tabular}{|c|c|c|c|c|}
\hline \multicolumn{4}{|c|}{ Group } & $\begin{array}{l}\text { No. of } \\
\text { Cases }\end{array}$ \\
\hline $\begin{array}{l}\mathbf{A} \\
\mathbf{B} \\
\mathbf{C} \\
\mathbf{D}\end{array}$ & $\begin{array}{c}\text { Sjøgren's } \\
\text { Syndrome }\end{array}$ & $\begin{array}{l}\text { With classical or defin } \\
\text { toid arthritis } \\
\text { With possible rheumat } \\
\text { With scleroderma } \\
\text { With myopathy }\end{array}$ & $\begin{array}{l}\text { Theuma- } \\
\therefore \text { irthritis }\end{array}$ & $\begin{array}{r}17 \\
2 \\
2 \\
4\end{array}$ \\
\hline $\mathbf{E}$ & \multicolumn{2}{|c|}{ Sicca complex alone ... } & $\ldots$ & 15 \\
\hline
\end{tabular}

The mean age at the time of observation of Groups A and B was 47 years; Group C, 32 years; and Groups D and E, 54 years.

Salivary and Lacrimal Glands.-Table IV shows that all but three patients had keratoconjunctivitis sicca, 35 had symptoms of xerostomia, and twenty

\section{TABLE IV}

OCCURRENCE OF CERTAIN COMPONENTS OF SJØGREN'S SYNDROME IN NATIONAL INSTITUTES OF HEALTH SERIES (40 cases)

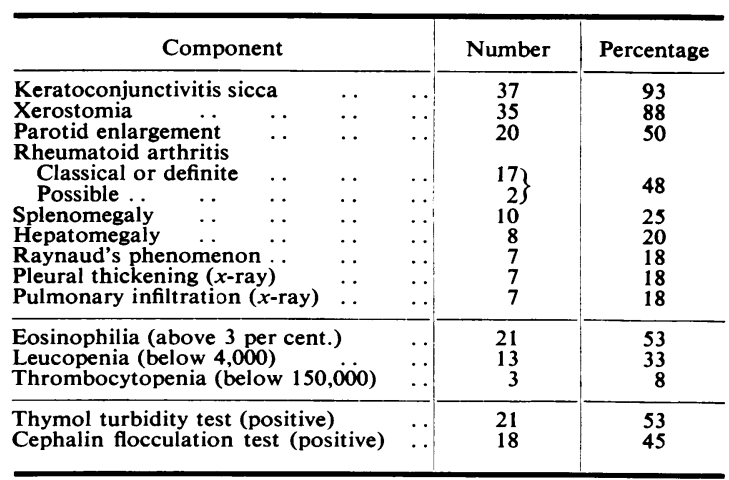


gave a history or presented signs of enlargement of the parotid gland. The clinical impression of keratoconjunctivitis sicca was supported by typical biomicroscopic changes in the cornea, staining of the bulbar conjunctiva and cornea with rose-bengal dye, and diminished tear flow as measured by the Schirmer technique. The presence of xerostomia was documented by salivary flow studies. Secretory sialography was carried out on 31 of the forty patients. The sialogram was normal in only one case; mild to moderate changes (mild punctate to punctate patterns) were observed in sixteen, severe alterations (globular configuration) in seven, and advanced changes (cavitary or destructive pattern) in seven.

The microscopic alterations in the salivary and lacrimal glands have been previously characterized by others. Typically these consist of dense intralobular infiltration of lymphocytes, atrophy of acinar tissue, and proliferation of duct-lining cells. The cellular multiplication in the ducts results in narrowing or obliteration of the ductal lumen and often in the formation of solid cell masses or "epi-myoepithelial islands". The lobular architecture by and large remains intact.

Biopsy of the parotid or submaxillary gland in thirteen patients in our series revealed extensive accumulations of lymphocytes and plasma cells with reduction of acinar parenchyma in almost all cases, proliferation of duct epithelium in eleven cases, and more advanced changes with formation of epi-myoepithelial islands in seven cases.*

A similar infiltrative process may occur in the mucous glands of the pharynx and larynx, and in the submucous glands of the oesophagus (Cardell and Gurling, 1954), trachea, and bronchi (Bucher and Reid, 1959).

Vasculitis.-This had been observed previously at autopsy in three cases of Sjøgren's syndrome associated with rheumatoid arthritis. The vascular lesions were described as periarteritis nodosa (Cardell and Gurling, 1954), acute necrotizing arteritis (Haas, 1951), and arteritis (Bucher and Reid, 1959). Since arteritis is very likely an integral part of the systemic pathological changes in rheumatoid disease, its occurrence in the above three cases may have been a manifestation of rheumatoid disease. However, Ramage and Kinnear (1956) reported a case of Sjøgren's syndrome not associated with rheumatoid arthritis in which polyarteritis nodosa was found at necropsy. In our series

\footnotetext{
* Other causes of salivary gland enlargement (such as leukaemia lymphoma, sarcoidosis, tuberculosis, cirrhosis, malnutrition, and Waldenstrom's macroglobulinaemia) were ruled out.
}

arteritis was found in two cases of definite rheumatoid arthritis and in one of possible rheumatoid arthritis. Of special interest, however, was the presence of vasculitis in random skin and muscle $\overrightarrow{\vec{\rho}}$ biopsies of three cases of Sjøgren's syndromewithout rheumatoid arthritis and in the absence of $\frac{C}{0}$ corticosteroid therapy. This lesion was not ob- $\overline{\bar{c}}$ served in seventeen other patients in our series who $\underset{\mathbb{D}}{\mathrm{D}}$ were subjected to muscle biopsy.

Two of the patients with arteritis had peripheral कै neuropathy. Sensory and motor changes were $\vec{\circ}$ evident in the lower extremities and sensory changes $\overrightarrow{-}$ alone in the upper. The neuropathy was mild in $\omega_{\sigma}$ one case and disabling in the other.

Skeletal Muscle Involvement.-Myopathy (called î

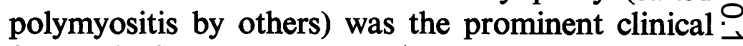
feature in four cases. Muscle weakness was severe -

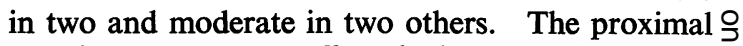
muscle groups were affected almost exclusively in three cases, while in the fourth both proximal and distal weakness were present. Muscle tenderness was absent in all four cases. Sensory function remained intact except for slight impairment of $\vec{\vartheta}$ vibration sense in the lower extremities in three $\stackrel{-}{-}$ cases. The diagnosis of myopathy was confirmed electromyographically and histologically by muscle biopsy in each case.

It is evident that Sjøgren's syndrome may occur in association with full-blown myopathy or poly- $\mathbb{D}$ myositis and would thus seem to be similarly related $\stackrel{2}{\Rightarrow}$ to this entity as it is to rheumatoid arthritis, sclero- $\frac{O}{3}$ derma, and other connective tissue diseases.

Muscle biopsies were also done in nineteen of 36 cases without clinical evidence of myopathy. Mild chronic focal myositis was present in eleven patients, severe myositis in one patient with scleroderma, and moderate myositis in one patient with sicca cornplex alone. In a second patient of the 8 latter grciup, granulomatous myositis was observed.

Other Clinical and Laboratory Components.-옥 Splenomegaly was present in ten cases, hepato- $\frac{T}{0}$ megaly in eight, Raynaud's phenomenon in seven, and $x$-ray evidence of pleural thickening in seven $\mathcal{N}$ and of chronic, basilar, mottled, and streaky $N$ infiltration in seven (Table IV). Eosinophilia N (above 3 per cent.) occurred in 21, leucopenia (below $\omega$ 4,000 per c.mm.) in thirteen, and thrombocytopenia (below 150,000 per c.mm.) in three. Five patients $\stackrel{\varrho}{=}$ had concurrent splenomegaly and leucopenia. In $\stackrel{\oplus}{\oplus}$ two of these, rheumatoid arthritis (Felty's syndrome) was also present. The thymol turbidity and cephalin flocculation tests were abnormal in 21 and 18 cases, respectively. These changes probably reflect alterations in serum protein rather than liver disease. 
It is noteworthy that in 21 of the forty cases, a history of drug sensitivity was elicited. Of eight patients with rheumatoid arthritis known to have received gold, six had developed toxic reactions.

Renal Function Studies.-The frequent occurrence in our series of low urinary specific gravity not associated with proteinuria or other urinary abnormalities prompted more extensive study of renal concentrating ability in ten patients. In four, the ability to concentrate urine was decidedly abnormal. After 18 hours' dehydration and the administration of the anti-diuretic hormone, vasopressin, the mean milliosmol values in the four patients ranged from 362 to 665 ; the normal being above 900 . All four had severe dryness of the mouth and two had definite polydypsia and polyuria. Since these patients had xerostomia, excessive water drinking as seen in psychogenic polydypsia first occurred to us as an explanation for the conspicuous hyposthenuria. However, when prolonged dehydration for 11 or 12 days failed to produce an increased urinary osmolality, this explanation became less tenable. Creatinine clearance tests were moderately abnormal in three and borderline in the fourth patient, but did not indicate renal impairment of a degree that would account for this lack of concentrating ability. Alternatively, the low urinary specific gravity may be explained by some organic lesion in the renal medulla which may have impaired primarily the tubular concentrating mechanism. At any rate, we have been so far unable to assess the full significance of the relationship of hyposthenuria in Sjøgren's syndrome. Bucher and Reid (1959) found at necropsy, in a case of Sjøgren's syndrome, dense infiltration of plasma cells and lymphocytes between the tubules in the medullary region. In that case, however, glomerulitis was also present.

\section{Serological Studies}

Serum Proteins.-Results of serum protein determinations in each of the five clinical groups previously delineated and in fifty normal controls are summarized graphically in the Figure (overleaf). Bars represent average values and the ranges of individual concentrations are indicated by brackets. In all groups the average serum albumin concentration was reduced below $3.4 \mathrm{~g}$. per cent. The average serum globulin was increased above $3.5 \mathrm{~g}$. per cent. Elevation of globulin was due chiefly to increase in gamma globulin, particularly the gamma 2 fraction, which on analytical ultracentrifugation proved to be the 7S type. Hyperglobulinaemia was present in every patient with myopathy (Group D) and in most patients with the sicca complex alone (Group E).

Rheumatoid Factor.-The results of tests for the rheumatoid factor by the bentonite flocculation test (BFT) on whole serum and the sensitized sheep cell agglutination test (SSCAT) on the euglobulin fraction, are presented in Table V. The BFT was positive in titres of $1: 64$ or higher in all cases, and the SSCAT in 83 per cent. of cases. This discrepancy may be due in part to the difference in sensitivity of the two tests. In three cases with sicca complex alone, moderate or high BFT titres and negative SSCA tests were encountered. Of special interest is the presence of rheumatoid factor in every one of the nineteen patients in Groups D and $E$, none of whom had rheumatoid arthritis or other connective tissue disease.

Antinuclear Factor.-The presence of antinuclear factor was detected by the indirect immunofluorescent technique, using as substrate frozen sections of mouse liver tissue. The sera of patients

TABLE V

SEROLOGICAL REACTIONS IN FORTY CASES OF SJØGREN'S SYNDROME

\begin{tabular}{|c|c|c|c|c|c|c|c|c|c|c|}
\hline & \multicolumn{6}{|c|}{ Group } & $\begin{array}{l}\text { Positive } \\
\text { BFT }\end{array}$ & $\begin{array}{l}\text { Positive } \\
\text { SSCAT }\end{array}$ & $\begin{array}{l}\text { Antinuclear } \\
\text { Factor* }\end{array}$ & $\begin{array}{c}\text { Positive Comple- } \\
\text { ment Fixation } \\
\text { Test (Liver) }\end{array}$ \\
\hline $\mathbf{A}$ & \multicolumn{6}{|c|}{ With definite rheumatoid arthritis .. } & $17 / 17$ & $14 / 17$ & $9 / 15(16) \dagger$ & $2 / 17$ \\
\hline B & \multirow{3}{*}{$\begin{array}{l}\text { Sjøgren's } \\
\text { Syndrome }\end{array}$} & \multicolumn{5}{|c|}{ With possible rheumatoid arthritis .. } & $2 / 2$ & $2 / 2$ & $1 / 2$ & $2 / 2$ \\
\hline $\mathrm{C}$ & & \multicolumn{3}{|c|}{ With scleroderma } & $\cdots$ & $\cdots$ & $2 / 2$ & $2 / 2$ & $2 / 2(256)$ & $0 / 2$ \\
\hline D & & \multicolumn{3}{|c|}{ With myopathy } & $\cdots$ & $\ldots$ & $4 / 4$ & $4 / 4$ & $2 / 2(64)$ & $2 / 3$ \\
\hline \multirow[t]{2}{*}{$\mathbf{E}$} & \multicolumn{2}{|c|}{ Sicca complex alone } & . & . & $\cdots$ & . & $15 / 15$ & $11 / 15$ & $10 / 10(64)$ & $13 / 15$ \\
\hline & Total. & . & . & . & $\cdots$ & . & $\begin{array}{c}40 / 40 \\
(100 \%)\end{array}$ & $\begin{array}{c}33 / 40 \\
(83 \%)\end{array}$ & $\begin{array}{c}24 / 31 \\
(77 \%)\end{array}$ & $\begin{array}{c}19 / 39 \\
(49 \%)\end{array}$ \\
\hline
\end{tabular}

* By immuno-fluorescent technique with intact nuclei.

+ Figures in ( ) are reciprocals of median titres. 


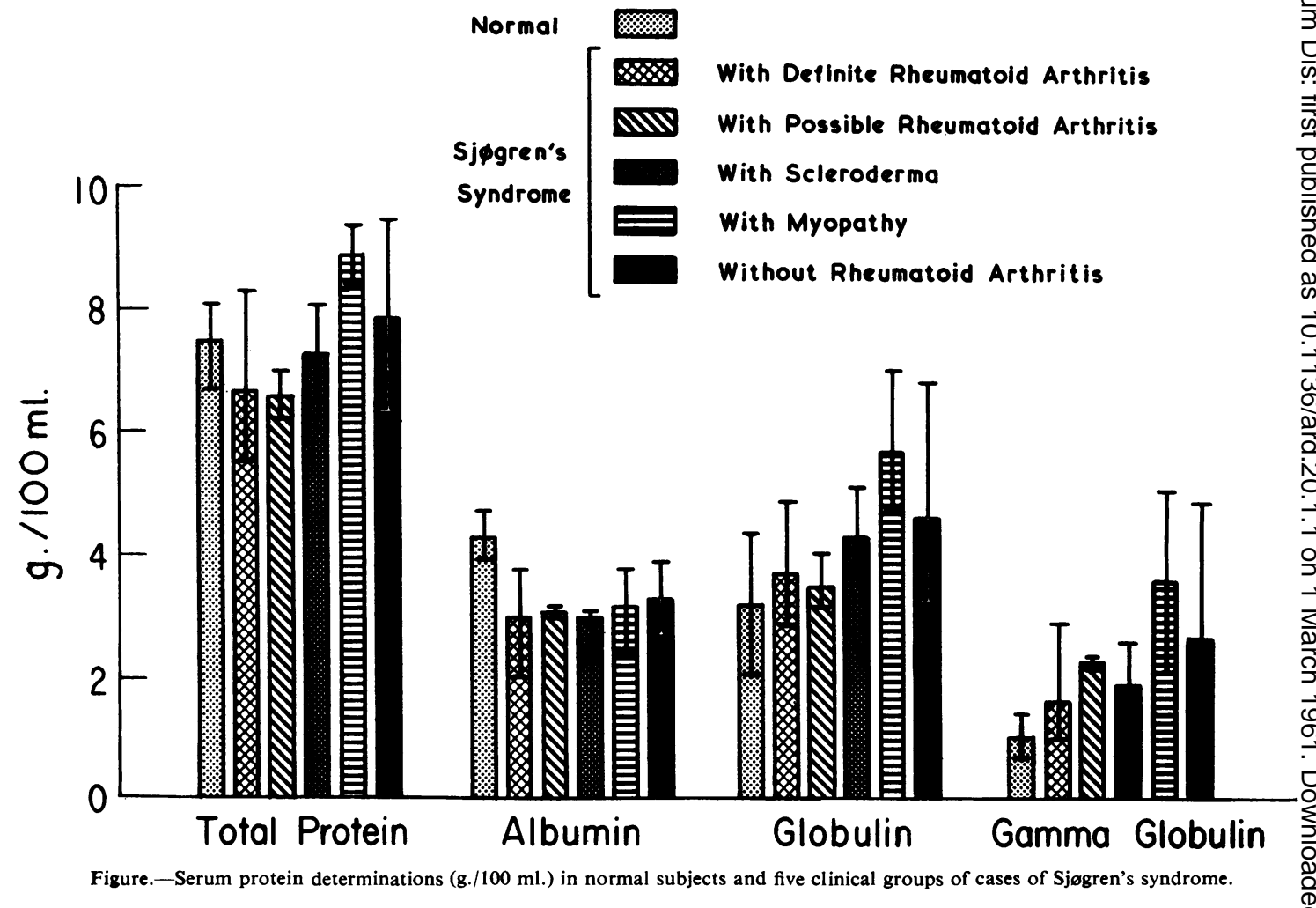

tested were diluted serially to determine the titre for this factor; 77 per cent. of sera examined for this constituent were positive (Table V). Again it will be noted that the serum of every patient tested in Groups D and E contained this reactive substance and the median titre was $1: 64$. 60 per cent. of the patients with definite rheumatoid arthritis (Group A) exhibited positive reactions with a median titre of $1: 16$. In contrast, only 13 per cent. of 31 patients with rheumatoid arthritis without Sjøgren's syndrome were positive. The specific nuclear constituent involved in these reactions is as yet undetermined. Repeated L.E. cell tests were performed in each of the forty cases of Sjøgren's syndrome and were found to be positive in only three; and these three had severe rheumatoid arthritis.

Complement-Fixing Antibodies.-An attempt was made by complement-fixation techniques to demonstrate organ specific antibodies to salivary glands in sera of patients with Sjøgren's syndrome. Experiments using a 10 per cent. suspension of human submaxillary gland as antigen demonstrated complement fixation, but it soon became apparent that human liver, kidney, thyrotoxic and normal thyroid, $\overrightarrow{\vec{O}}$ and some striated muscle preparations provided antigens of approximately equal reactivity. Table $V_{F}$ presents the results of complement-fixation reactions with the liver homogenate; 49 per cent. of $39 \cong$ patients with Sjøgren's syndrome fixed complement, the median titre being $1: 360$. Groups $D$ and $E ב$. again distinguish themselves from the others in the high incidence of complement-fixing antibodies; 83 per cent. in contrast to 12 per cent. in the cases of rheumatoid arthritis associated with Sjøgren's syndrome. Moreover, the two patients in Group A음 had titres of only $1: 40$ and $1: 120$, whereas the median titre of the thirteen patients in Group EN was $1: 1,000$. Differential ultracentrifugation of $N$ the tissue homogenates indicated that the activen fraction in the complement-fixation test remains in ${ }_{\sigma}^{\omega}$ the supernatant and does not sediment with the

nuclei, mitochondria, or microsomes.
The reactions described appear to be analogous with those reported in the past 3 years from labora- tories in several countries, including Australia, Great Britain, and the United States (Gajdusek,

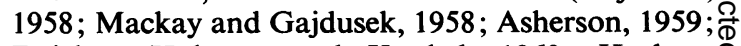
Deicher, Holman, and Kunkel, 1960; Hackett, $\cong$ 
Beech, and Forbes, 1960). These investigators found that sera of patients with certain chronic diseases fixed complement in the presence of human tissue homogenates (liver, kidney, lung, adrenal, and thyroid). Of the rheumatic diseases, systemic lupus erythematosus (SLE) was most prominent in their studies. It now appears that similar antibodies also occur in Sjøgren's syndrome.

Our previous efforts to demonstrate precipitating antibodies to extracts of salivary glands in agar gel were unrewarding; however, current experiments using the patients' isolated gamma globulins and incubation at $37^{\circ} \mathrm{C}$. have been more satisfactory. Precipitin lines were obtained with serum gamma globulins from several patients with Sjøgren's syndrome and extracts from human liver, kidney, submaxillary gland, thyroid, and normal pooled gamma globulin. This reaction did not occur with controls.

\section{Thyroid Studies}

Because of the analogous histological alterations in Hashimoto's thyroiditis and Sjøgren's syndrome, examination for clinical and laboratory evidence of thyroid disease or dysfunction was carried out in each case. In addition, sera were tested for thyroglobulin antibodies by haemagglutination tests using tanned erythrocytes coated with relatively pure thyroglobulin. Eleven of the forty patients had a positive tanned cell red cell agglutination test in titres ranging from $1: 16$ to $1: 25,000$. Of the eleven patients with thyroglobulin antibodies (Table VI), six had no clinical or laboratory evidence of thyroid disease, while five had either diffuse or nodular thyroid enlargement. Of these five, three were subjected to surgery; the tissue sections in two of them revealed diffuse changes consistent with Hashimoto's thyroiditis, and a thyroid nodule in the third case showed a few small foci of interstitial lymphocyte infiltration. One additional patient who had a negative thyroglobulin haemagglutination test had hypothyroidism. In this

TABle VI

OCCURRENCE OF THYROID ANTIBODIES AND THYROID DISEASE IN FORTY CASES OF SJØGREN'S SYNDROME

\begin{tabular}{|c|c|c|c|c|c|c|}
\hline \multicolumn{3}{|c|}{ Thyroglobulin Antibodies } & . & $\cdots$ & Present & Absent \\
\hline \multicolumn{2}{|c|}{ Number of Patients } & $\ldots$ & . & $\ldots$ & 11 & 29 \\
\hline $\begin{array}{l}\text { Thyroid } \\
\text { Disease }\end{array}$ & \multicolumn{3}{|c|}{$\begin{array}{l}\text { Nodular goitre ... } \\
\text { Diffuse enlargement }\end{array}$} & $\begin{array}{l}\ldots \\
\ldots \\
.\end{array}$ & $\begin{array}{l}3(1) \\
2(1) \\
6\end{array}$ & $\begin{array}{c}1^{*} \\
28\end{array}$ \\
\hline
\end{tabular}

( ) Hashimoto's thyroiditis.

- Hypothyroidism. series, then, five patients had both thyroid disease and thyroglobulin antibodies, but six of 34 (18 per cent.) had thyroglobulin antibodies without overt thyroid disease.* In this connexion it should be noted that Hackett, Beech, and Forbes (1960) reported that 30 per cent. of women over forty years of age admitted to the Royal Adelaide Hospital without clinically recognizable thyroid disease had positive thyroglobulin haemagglutination tests.

Sera of 129 relatives of eleven consecutive patients in our series and of 46 relatives of six control subjects were tested for thyroglobulin antibodies by the tanned red cell technique. The prevalence was 16 per cent. in the patients' relatives and 11 per cent. in relatives of controls. Of eleven patients' families studied, eight (72 per cent.) had two or more members with thyroglobulin antibodies, whereas only one of six (17 per cent.) control families exhibited this phenomenon. This difference would become statistically significant if sustained in a larger number of control and patient relatives. It is interesting that eleven of 21 relatives of patients had antibody titres of $1: 1,024$ or higher, whereas none of the relatives of controls had titres above $1: 256$. Extended family studies are currently in progress and will be reported subsequently.

Hall, Owen, and Smart (1960) searched for thyroid antibodies in the sera of 39 siblings of eleven propositi with various types of thyroid disease (only one had Hashimoto's thyroiditis). Antibodies were found in 56 per cent. and half of these had no clinical evidence of thyroid disease. The authors concluded tentatively from these data that the predisposition to develop auto-antibodies to thyroid is inherited as a dominant characteristic.

The preliminary report by Hall and his associates requires confirmation. Determination of the significance of the difference in incidence of thyroglobulin antibodies in the relatives of propositi with Sjøgren's syndrome compared to that in the relatives of controls awaits completion of the family studies. It is conceivable that a genetic relationship exists between the occurrence of thyroglobulin antibodies and the development of Hashimoto's thyroiditis on the one hand and Sjøgren's syndrome on the other. In this regard, it is of special interest that Hashimoto's thyroiditis has occurred in 5 per cent. of our cases of Sjøgren's syndrome.

\footnotetext{
* The association of positive complement-fixation reaction employing antigens obtained from several tissues, including thyroid, with positive thyroglobulin haemagglutination reactions in some of the same sera may raise doubts as to the specificity of the latter. Indirect evidence suggests that these two phenomena are indeed independent of each other. Many sera which fixed complement in the presence of tissue homogenates did not react with thyroglobulinthe presence of tissue homogenates did not react with thyroglobulineither failed to fix complement in the presence of any tissue homoeither failed to fix complement in the presence of any tisst
genate or did so only with thyrotoxic thyroid homogenate.
} 


\section{Discussion}

It is quite apparent that Sjøgren's syndrome, like systemic lupus erythematosus and rheumatoid arthritis, is a multisystemic disease. These conditions not only share certain clinical, pathological, biochemical, and serological characteristics, but also may indeed occur concurrently. Although the sicca syndrome is much more commonly associated with rheumatoid arthritis than with systemic lupus erythematosus, the high incidence of circulating antibodies to various tissue components in cases of Sjøgren's syndrome without rheumatoid arthritis provides a noteworthy similarity to systemic lupus erythematosus. The analogy between Sjøgren's syndrome and Hashimoto's thyroiditis is even more impressive.

Since efforts to discover the aetiology of rheumatoid arthritis and related diseases by employing older disciplines such as pathology, microbiology, and biochemistry have produced inconclusive results, the recent surge of interest in auto-immunity is understandable. While it is tempting to attribute pathogenic significance to circulating antibodies which act against tissue components in vitro (and the heuristic value of this concept is undeniable), one must examine critically the evidence thus far produced.

The criteria for an auto-immune disease as proposed by Witebsky and others (1957) consist of:

(1) Demonstration of circulating or cell-bound antibodies;

(2) Recognition of specific antigen against which this antibody is directed;

(3) Production of antibody against the same antigen in experimental animals;

(4) Appearance of pathological changes in the corresponding tissues of an actively sensitized experimental animal that are similar to those in human disease.

These criteria have not been fulfilled as yet in systemic lupus erythematosus, rheumatoid arthritis, or Sjøgren's syndrome. Circulating antibodies in Sjøgren's complex, with the exception of thyroglobulin antibodies, are neither organ nor species specific and a specific antigen has not yet been isolated or characterized chemically. Moreover, rabbits injected with homologous salivary gland homogenates and guinea-pigs injected with lacrimal glands homogenates in Freund's adjuvant failed to develop lesions in these organs (Bloch and McMaster, 1960).

It is still questionable whether the gamma globulins that participate in the serological reactions observed in these rheumatic diseases fulfil the criteria of classical antibodies. Are these so-called "anti- bodies" produced in response to specific antigenic stimulation? Is it possible that the serological reactions may represent a relatively non-specific protein-protein interaction between a tissue component and a serum globulin that has been altered by a non-immunological process? Similar questions have arisen in well-studied test systems, such as the Wassermann reaction, and still await solution. Until further information is obtained concerning the significance of antibodies to tissue components, we must be conservative in our conclusions concerning their role in pathogenesis of disease.

However, the fact remains-all reservations and qualifications notwithstanding - that there is in Sjøgren's syndrome and in certain connective tissue diseases, a high frequency of positive serological reactions, not only in the patients but also in an impressive percentage of their relatives. Could it be that the circulating factors with antibody-like characteristics do not necessarily act as the primary or direct pathogenic agent, but in some way alter the resistance of the host to subsequent attacks by as yet unidentified noxious agents? Such change in host resistance may be at the cellular level. It is conceivable that the presence of a circulating factor may merely reflect, and be of secondary importance to, the presence of cell-bound factors which thus far have eluded detection. Finally, may the source of trouble lie in the cells of origin of these so-called "antibodies" which, because of genetic factors, synthesize certain proteins (globulins) abnormally?

\section{Summary}

The studies reported here have broadened the spectrum of Sjøgren's syndrome and have given additional support to Sjøgren's original impression that the disease is systemic. The association of this syndrome with rheumatoid arthritis seems significant, although the basis for this linkage remains unexplained. Several features which rheumatoid arthritis alone shares with Sjøgren's syndrome not associated with rheumatoid arthritis, such as vasculitis, neuropathy, and hyperglobulinaemia, are interesting. The high incidence of rheumatoid factor in this syndrome, even in the absence of rheumatoid arthritis, is intriguing. The unusual concurrence of Hashimoto's thyroiditis and Sjøgren's syndrome (especially in view of a similar histopathological response in both conditions) and the frequent occurrence of thyroglobulin antibodies in the patients of this series require further investigation. The pathogenic implications of the high frequency of circulating antibodies to tissue components in this syndrome, as in certain other chronic diseases, are provocative but remain as yet obscure. 
The interrelationship of the diverse diseases discussed in this lecture may be spurious, and I fear I may have compounded rather than reduced the confusion that currently envelops our concepts of the mechanism of these diseases. I confess that I have harboured the hope that what Lancelot Law Whyte said of theoretical science may apply to clinical science:

"The creative imagination rests on more than intense disinterested curiosity. The essential is the desire to understand multiplicity in terms of a single idea, to achieve insight by discovering a simple order within the apparent complexity. No one will undertake the effort of major discovery unless he is carried by an unquestioning, ardent belief, admitted or latent, that a simple underlying order exists or can be created."

The author wishes to acknowledge with gratitude the help generously given by Dr. G. M. Shy of the National Institute of Neurological Diseases and Blindness, who permitted us to study the four cases of myopathy; Dr. R. A. Malmgren of the National Cancer Institute, who performed the tests for antinuclear antibodies; Dr. M. Kahn of the National Heart Institute, who did the renal function studies, and Dr. R. M. Stephan of the National Institute of Dental Research, who performed the salivary flow studies. At the National Institute of Arthritis and Metabolic Diseases, Dr. L. Sokoloff examined the biopsy sections, Dr. T. A. Burch carried out the family studies, and Dr. N. J. Zvaifler and $M$. O. Robertson performed the complementfixation tests.

\section{REFERENCES}

Asherson, G. L. (1959). Brit. J. exp. Path., 40, 209.

Bloch, K. J., Bunim, J. J., Wohl, M. J., and Zvaifler, N. J. (1960). Trans. Ass. Amer. Physcns, 73, 166.

and McMaster, P., Jr. (1960). Unpublished data.

—, Wohl, M. J., Ship, I. I., Oglesby, R. B., and Bunim, J. J. (1960). Arthr. and Rheum., 3, 287.

Bucher, U. G., and Reid, L. (1959). Brit. J. Dis. Chest, $53,237$.

Cardell, B. S., and Gurling, K. J. (1954). J. Path. Bact., 68, 137.

Clegg, J. Gray (1927). Trans. ophthal. Soc. U.K., 47, 95.

Deicher, H. R., Holman, H. R., and Kunkel, H. G. (1960). Arthr. and Rheum., 3, 1.

Fischer, E. (1889). v. Graefes Arch. Ophthal., 35, 201.

Gajdusek, D. C. (1958). A.M.A. Arch. intern. Med., 101, 9.

Gaulhofer, W. K. (1954). Acta med. scand., 149, 441.

Haas, E. (1951). Virchows Arch. path. Anat., 320, 264.

Hackett, E., Beech, M., and Forbes, I. J. (1960). Brit. med. J., $2,17$.

Hadden, W. B. (1888). Trans. clin. Soc. Lond., 21, 176.
Hall, R., Owen, S. G., and Smart, G. A. (1960). Lancet, 2, 187.

Hashimoto, H. (1912). Arch. klin. Chir., Berl., 97, 219.

Houwer, A. W. M. (1927). Trans. ophthal. Soc. U.K., $47,88$.

Hutchinson, J. (1888). Trans. clin. Soc. Lond., 21, 180.

Jones, B. R. (1958). Lancet, 2, 773.

Lackington M., C., Charlin V., C., and Gormaz B., A. (1951). Rev. méd. Chile, 79, 233.

Leber, T. (1882). Ber. ophthal. Ges. Heidelberg, $14,165$.

Mackay, I. R., and Gajdusek, D. C. (1958). A.M.A. Arch. intern. Med., 101, 30.

Mikulicz, J. (1892). "Beiträge zur Chirugie", p. 610. Enke, Stuttgart. (Translated in Medical Classics, 2, 165, Oct. 1937.)

Morgan, W. S. (1954). New Engl. J. Med., 251, 5.

- and Castleman, B. (1953). Amer. J. Path., 29, 471.

Neuberger, A. (1960). Ann. rheum. Dis., 19, 1.

Oblatt, E., Fehér, L., and Csiky, T. (1958). Klin. Wschr., 36, 769 .

Ramage, J. H., and Kinnear, W. F. (1956). Brit. J. Ophthal., 40, 416.

Reader, S. R., Whyte, H. M., and Elmes, P. C. (1951). Ann. rheum. Dis., 10, 288.

Roitt, I. M., and Doniach, D. (1958). Lancet, 2, 1027.

Sjøgren, H. (1933). Acta ophthal. (Kbh.), Suppl. 2, 1 (translation by J. B. Hamilton, "A New Conception of Keratoconjunctivitis Sicca". Australasian Medical Publ. Co., Sydney, 1943).

(1951). Ibid., 29, 33.

Stenstam, T. (1947). Acta med. scand., 127, 130.

Stock (1925). In "Handbuch der gesamten Augenheilkunde", ed. A. Graefe and T. Saemisch, 2nd ed., Band 9, Abt. 3 and 4. Springer, Berlin.

Thompson, M., and Eadie, S. (1956). Ann. rheum. Dis., $15,21$.

Witebsky, E., Rose, N. R., Terplan, K., Paine, J. R., and Egan, R. W. (1957). J. Amer. med. Ass., 164, 1439.

Un spectre plus large du syndrome de Sjøgren et ses implications pathogénétiques

\section{RÉSUMÉ}

Les études présentées ici ont élargi le spectre du syndrome de Sjøgren et renforcé la première impression de Sjøgren qu'on y a à faire à une maladie générale. L'association de ce syndrome à l'arthrite rhumatismale semble significative, bien que la base de cette association demeure inexpliquable. De différents traits communs de l'arthrite rhumatismale pure et du syndrome de Sjøgren pur (c'est à dire non associé à l'arthrite rhumatismale), tels que vasculite, névropathie et hyperglobulinémie, sont intéressants. Il est aussi intrigant de trouver si souvent dans ce syndrome le facteur rhumatismal, même en l'absence de l'arthrite rhumatismale. La suprenante coëxistence de la thyroïdite de Hashimoto et du syndrome de Sjøgren (surtout en vue d'une réponse histopathologique similaire dans les deux maladies) et l'existence fréquente des anticorps contre la thyroglobuline chez des malades dans cette série demande aussi des recherches ultérieurs. Les implications pathogénétiques de la grande fréquence des anticorps circu- 
lants contre les composants tissulaires dans ce syndrome, comme dans certaines autres maladies chroniques, sont provocatrices mais toujours bien obscures.

\section{Un espectro más amplio del síndrome de Sjøgren y sus implicaciones patogénicas}

\section{SUMARIO}

Los estudios presentados aquí han ensanchado el campo del síndrome de Sjøgren y han dado un soporte adicional a la idea original de Sjøgren de que se trata de una enfermedad general. La asociación de este síndrome con la artritis reumatoide parece significativa, aunque la base de dicha asociación permanece inexplicada. Varias características que la artritis reuma- toide pura comparte con el síndrome de Sjøgren puro (no asociado con artritis reumatoide), tales como vasculitis, neuropatía y hiperglobulinemia, son interesantes. Es intrigante la alta frecuencia del factor reumatoide en este síndrome aún en ausencia de artritis reumatoide concomitante. La insólita concurrencia de la tiroiditis de Hashimoto y del síndrome de Sjøgren (especialmente en vista a una respuesta histopatológica similar en embas enfermedades) y la frecuente aparición de anticuerpos contra la tiroglobulina en enfermos de esta serie requiere posterior investigación. Las implicaciones patogénicas de la alta frecuencia de anticuerpos en circulación contra los componentes de los tejidos en este síndrome, en similitud con otras enfermedades crónicas, son provocativas pero todavía permanecen oscuras. 